\title{
Peningkatan Kompetensi Strategis Siswa Melalui Model Pembelajaran Conceptual Understanding Procedures
}

\author{
${ }^{1}$ Adriyanto, ${ }^{2}$ Dewi Pramita, ${ }^{3}$ Abdillah, ${ }^{4}$ Syaharuddin, ${ }^{5}$ Mahsup, ${ }^{6}$ Eka Fitriani \\ 1,2,3,4,5,6 Pendidikan Matematika, Universitas Muhammadiyah Mataram, Indonesia \\ 1adriyanto@gmail.com, ${ }^{2}$ mitha dhewi@yahoo.com, \\ 3ahmad fawwaz@yahoo.co.id, ${ }^{4}$ syaharuddin.ntb@gmail.com, ${ }^{5}$ supyeka@gmail.com , \\ ekaabata88@gmail.com
}

\begin{tabular}{l}
\hline ARTICLE INFO \\
\hline Article History: \\
Received $\quad: 02-03-2019$ \\
Revised $\quad: 13-05-2019$ \\
Accepted $\quad: 27-05-2019$ \\
Online $\quad: 30-05-2019$ \\
\\
Keywords; \\
Conceptual \\
Understanding \\
Procedures (CUPs); \\
Bangun Ruang Sisi Datar; \\
Kompetensi Strategis.
\end{tabular}

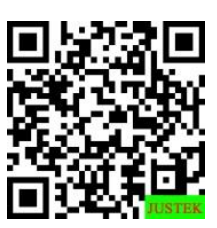

\begin{abstract}
Abstract: This study aims to determine the effectiveness of conceptual understanding procedures learning model to students' strategic competencies taken from student post-test results. The study was included in quasi Experimental Design research involving 41 students consisting of two classes taken from five classes with porposive sampling techniques. The data collection technique used is a test instrument with a significant level of $5 \%$. The results showed that the average strategic competency ability of experimental class students was 61.7, while the average strategic competency ability of control class students was 51 . Based on data analysis from the t-test hypothesis that has been done, the results showed $t$-count $>$ t-table $(2.43>1.69)$ so that Ho was rejected and $\mathrm{Ha}$ accepted. Therefore, it can be concluded that the Conceptual Understanding Procedures learning model is effective against the strategic competencies of students in the material of building flat-sided rooms in grade VIII junior high school.
\end{abstract}

\begin{abstract}
Abstrak: Penelitian ini bertujuan untuk mengetahui efektifitas model pembelajaran Conceptual Understanding Procedures terhadap kompetensi strategis siswa yang diambil dari hasil post-test siswa. Penelitian ini termasuk dalam penelitian Quasi Eksperimental Design yang melibatkan 41 siswa yang terdiri dari dua kelas yang diambil dari lima kelas dengan teknik porposive sampling. Teknik pengumpulan data yang digunakan adalah instrumen tes dengan taraf signifikan 5\%. Hasil penelitian menunjukkan, rata-rata kemampuan kompetensi strategis siswa kelas eksperimen sebesar 61,7, sedangkan rata-rata kemampuan kompetensi strategis siswa kelas kontrol sebesar 51. Berdasarkan analisis data dari uji hipotesis uji- $t$ yang sudah dilakukan, hasilnya menunjukkan t-hitung $>$ t-tabel $(2,43>1,69)$ sehingga $\mathrm{H}_{\mathrm{o}}$ ditolak dan $\mathrm{H}_{\mathrm{a}}$ diterima. Oleh sebab itu, dapat disimpulkan bahwa model pembelajaran Conceptual Understanding Procedures efektif terhadap kompetensi strategis siswa pada materi bangun ruang sisi datar kelas VIII SMP.
\end{abstract}

\section{A. LATAR BELAKANG}

Pendidikan nasional berfungsi mengembangkan kemampuan dan membentuk watak serta peradaban bangsa yang bermartabat dalam rangka mencerdaskan bangsa (UURI 2003)(Dantes 2007). Salah satu upaya untuk meningkatkan mutu pendidikan di sekolah adalah memperbaiki proses pembelajaran (Sistem Pendidikan Nasional 2003). Proses 
pembelajaran menggunakan berbagai metode dan strategi dalam pelaksanaannya (Permendikbud RI No. 20 2016) . Berbagai metode dan strategi baru dalam proses pembelajaran di sekolah telah muncul dan berkembang seiring dengan perkembangan ilmu pengetahuan dan teknologi (Mahsup, Abdillah 2018).

Pendidikan adalah satu bentuk perwujudan kebudayaan manusia yang dinamis dan syarat perkembangan (Setyowati, Kristin, and Anugraheni 2018). Oleh karena itu, perubahan atau perkembangan pendidikan adalah hal yang memang seharusnya terjadi sejalan dengan perubahan budaya kehidupan (Aribawati, Kristin, and ... 2018). Perubahan dalam arti perbaikan pendidikan pada semua tingkat perlu terus-menerus dilakukan sebagai antisipasi kepentingan masa depan (Puspita, Slameto, and ... 2018).

Inovasi dalam penerapan model pembelajaran dilakukan pada semua mata pelajaran yang diajarkan tidak terkecuali pada pembelajaran matematika (Kabunggul et al. 2020). Berbagai model dan metode pembelajaran tersebut diterapkan guna menciptakan situasi belajar yang lebih kondusif (Mahsup and Anwar 2020). Lebih-lebih lagi, dengan diterapkan berbagai model dan metode tersebut, diharapkan kesan peserta didik terhadap matematika berubah. Kesan yang diharapkan yakni matematika bukanlah pelajaran yang selamanya membosankan dan dirasakan sulit (Arta Diantoro, Mahsup, and Pramita 2019).

Penggunaan model dan metode pembelajaran yang tepat akan turut menentukan efektifitas dan efisiensi pembelajaran (Muhardini et al. 2020). Penggunaan model pembelajaran yang sesuai dengan kebutuhan materi pembelajaran dan gaya belajar siswa juga sangatlah penting agar dapat menunjang minat dan motivasi belajar peserta didik (Rahmatin et al. 2019). Seperti pada pembelajaran matematika, kemampuan pemahaman konsep merupakan syarat mutlak dalam mencapai keberhasilan belajar (Dwiranata, Pramita, and Syaharuddin 2019). Hanya dengan penguasaan konsep seluruh permasalahan dalam matematika dapat dipecahkan, baik itu permasalahan dalam bentuk soal disekolah ataupun permasalahan dalam kehidupan sehari-hari (Syaharuddin, Pramita, and Sirajuddin 2019). Hal ini menunjukkan bahwa pelajaran matematika bukanlah pelajaran hafalan tetapi lebih menuntut kepada pemahaman konsep dan latihan (Syaharuddin, Pramita, and Sirajuddin 2019).

Berdasarkan hasil observasi dan wawancara dengan guru di kelas VIII SMP Negeri 2 Labuapi, proses pembelajaran masih berlangsung dengan metode langsung dan ceramah, yang mana proses pembelajarannya masih berpusat pada guru. Hal ini terus berlangsung pada setiap pertemuan dalam proses belajar mengajar. Oleh sebab itu, proses belajar tersebut dapat dikatakan pembelajaran yang kurang bervariasi. Dalam proses pembelajaran dibutuhkan variasi model dan metode mengajar untuk meningkatkan motivasi dan kejenuhan siswa dalam belajar. Sebagai gambaran dari situasi ini, bisa dilihat dari perolehan nilai rata-rata ulangan mata pelajaran lingkaran.

Tabel 1. Nilai Rata-rata Ulangan Mata Pelajaran Lingkaran

\begin{tabular}{cccc}
\hline No & Kelas & Jumlah Siswa & Nilai Rata-rata \\
\hline 1 & VIII C & 21 & 47,35 \\
\hline 2 & VIII E & 20 & 45,64 \\
\hline
\end{tabular}


Berdasarkan Tabel 1 menunjukkan nilai rata-rata siswa masih jauh dari standar KKM yang ada disekolah yaitu $\geq 70$. Berarti pengetahuan siswa pada materi lingkaran masih rendah. Pemilihan model pembelajaran diharapkan dapat menjadi solusi yang tepat dan turut menentukan efektifitas serta efisiensi dalam pembelajaran, agar dapat menunjang minat dan motivasi belajar siswa. Salah satu model pembelajaran yang dinilai efektif yaitu model pembelajaranconceptual understanding procedures (CUPs), dalam pelaksanaan pembelajaran dengan menggunakan model pembelajaran CUPs siswa dibagi ke dalam kelompok kecil yang terdiri dari tiga orang (triplet) yang dibentuk secara heterogen, dengan mempertimbangkan kemampuan siswa dan bahan diskusi yang diberikan kepada siswa. Guru lebih berperan sebagai fasilitator, membantu mengaktifkan siswa tersebut dalam pembentukan pengetahuan (Gita, Murnaka, and Sukmawati 2018).

Adapun kelebihan CUPs yaitu memperdalam pemahaman siswa, melatih tanggung jawab siswa, meningkatkan rasa percaya diri dan mengembangkan rasa saling memiliki serta kerjasama (Hikmah, Baidowi, and Kurniati 2014). Penggunaan model pembelajaran CUPs diharapkan dapat meningkatkan dan menunjukkan hasil pembelajaran yang dilakukan siswa, seperti kemampuan matematis siswa, salah satunya yaitu kompetensi strategis (Ade Rahayu Fadhilla, AR, and Susilawati 2016). Dimana kompetensi strategis adalah suatu kegiatan berpikir secara logis antara konsep dan situasi dengan mengaitkan jawaban dan alasan yang diberikan (Herianto and Ibrahim 2017). Adapun tujuan dalam pelaksanaan penelitian ini adalah untuk mengetahui efektifitas model pembelajaran Conceptual Understanding Procedures terhadap kompetensi strategis siswa SMP Negeri 2 Labuapi kelas VIII.

\section{B. METODE PENELITIAN}

Penelitian ini dilakukan dengan menggunakan metode quasi eksperimen, dimana metode ini tidak memungkinkan peneliti melakukan pengotrolan penuh terhadap faktor lain yang mempengaruhi variabel dan kondisi eksperimen (Arikunto 2006)(Sugiyono 2013). Dalam pelaksanaannya, rancangan penelitian menggunakan desain Possttest-Only Control Group Design. Desain eksperimen ini memiliki dua kelompok yaitu: kelompok pertama yang mendapatkan perlakuan (treatment) sedangkan kelompok kedua merupakan pengendali (Control). Penelitian ini dilakukan terhadap siswa SMPN 2 Labuapi kelas VIII semester genap dengan objek penelitian kelas VIII.C sebanyak 21 orang dan VIII.E sebanyak 20 orang. Sampel dalam penelitian ini adalah siswa kelas VIII.C dan VIII.E SMP Negeri 2 Labuapi. Instrumen dalam penelitian ini adalah soal tes. Tes diginakan untuk mengukur suatu masalah berdasarkan variabel yang akan diteliti.

Untuk memperoleh skor kemampuan kompetensi strategis matematik siswa, diperluan pedoman penskoran terhadap jawaban siswa sesuai Tabel 3.

Tabel 2. Pedoman PenskoranSoal Tes Akhir

\begin{tabular}{|c|c|c|c|}
\hline Skor & $\begin{array}{l}\text { Mampu mengembangkan } \\
\text { metode penyelesaian } \\
\text { yang efektif dalam } \\
\text { menyelsaikan suatu } \\
\text { permasalahan }\end{array}$ & $\begin{array}{c}\text { Mampu menyajikan } \\
\text { masalah secara } \\
\text { matematik }\end{array}$ & $\begin{array}{l}\text { Mampu } \\
\text { menemukan solusi } \\
\text { dari permasalahan } \\
\text { yang diberikan }\end{array}$ \\
\hline
\end{tabular}




\begin{tabular}{|c|c|c|c|}
\hline 3 & $\begin{array}{l}\text { Menunjukkan } \\
\text { pengembangan metode } \\
\text { penyelesaian yang efektif } \\
\text { secara keseluruhan } \\
\text { dengan benar, jelas, dan } \\
\text { lengkap }\end{array}$ & $\begin{array}{lr}\text { Menunjukkan } & \text { penyajian } \\
\text { masalah } & \text { secara } \\
\text { matematik } & \text { secara } \\
\text { keseluruhan } & \text { dengan } \\
\text { benar, jelas, dan lengkap }\end{array}$ & $\begin{array}{l}\text { Menunjukkan } \\
\text { penemuan solusi } \\
\text { dari permasalahan } \\
\text { secara keseluruhan, } \\
\text { jelas ,dan lengkap }\end{array}$ \\
\hline 2 & $\begin{array}{l}\text { Menunjukkan } \\
\text { pengembangan metode } \\
\text { penyelesaian yang efektif } \\
\text { (hampir semua) dengan } \\
\text { benar. }\end{array}$ & $\begin{array}{lr}\text { Menunjukkan } & \text { penyajian } \\
\text { masalah } & \text { secara } \\
\text { matematik } & \text { (hampir } \\
\text { semua) dengan benar. }\end{array}$ & $\begin{array}{l}\text { Menunjukkan } \\
\text { penemuan solusi } \\
\text { dari permasalahan } \\
\text { (hampir semua) } \\
\text { dengan benar. }\end{array}$ \\
\hline 1 & $\begin{array}{l}\text { Menunjukkan } \\
\text { pengembangan metode } \\
\text { penyelsaian yang efektif } \\
\text { (hanya sebagian) dengan } \\
\text { benar. }\end{array}$ & $\begin{array}{lr}\text { Menunjukkan } & \text { penyajian } \\
\text { masalah } & \text { secara } \\
\text { matematik } & \text { (hanya } \\
\text { sebagian) dengan benar. }\end{array}$ & $\begin{array}{l}\text { Menunjukkan } \\
\text { penemuan solusi } \\
\text { dari permasalahan } \\
\text { (hanya sebagian) } \\
\text { dengan benar. }\end{array}$ \\
\hline
\end{tabular}

Uji hipotesis akhir bertujuan untuk mengetahui tingkat kemampuan siswa. Hasil yang diharapakan dari uji hipotesis akhir adalah adanya perbedaan kemampuan siswa kelas eksperimen dan kelas kontrol. Hipotesis nol $\left(\mathrm{H}_{0}\right)$ diharapkan ditolak dan hipotesis alternatif (Ha) diterima.

\section{HASIL DAN PEMBAHASAN}

\section{Hasil uji coba instrument}

Sebelum instrumen digunakan dalam pengumpulan data,instrumen tersebut diuji coba untuk mengetahui tingkat validitas dan reliabilitas instrumen. Adapun tujuannya adalah mengetahui tingkat kepercayaan instrumen guna memeperoleh kesimpulan yang benar. Uji coba instrumen dilakukan terhadap kelas IX sebanyak 24 responden diluar sampel penelitian. Jenis instrumen yang digunakan adalah isian dengan jumlah item soal sebanyak 4 soal.

a. Uji validitas instrumen penelitian

Validitas bertujuan untuk mengetahui kemampuan alat ukur terhadap konsep yang diuji. Perhitungannya dilakukan dengan menggunakan rumus korelasi Product Moment. Berdasarkan perhitungan yang dilakukan terhadap empat item soal, hasilnya menunjukkan bahwa keempat item soal tersebut valid dengan taraf signifikasi $5 \%$ dan $r_{\text {tabel }}=0,388$. Berikut hasil perhitungan validitas empat item soal disajikan dalam Tabel 3.

Tabel 3. Hasil Uji Validitas Instrumen

\begin{tabular}{ccccc}
\hline $\begin{array}{c}\text { Item } \\
\text { butir soal }\end{array}$ & $\mathrm{N}$ & $\boldsymbol{r}_{\text {hitung }}$ & $\boldsymbol{r}_{\text {tabel }}$ & Keputusan \\
\hline $\mathrm{X}_{1}$ & 24 & 0,798 & 0,388 & Valid \\
\hline $\mathrm{X}_{2}$ & 24 & 0,642 & 0,388 & Valid \\
\hline $\mathrm{X}_{3}$ & 24 & 0,465 & 0,388 & Valid \\
\hline $\mathrm{X}_{4}$ & 24 & 0,800 & 0,388 & Valid \\
\hline
\end{tabular}


Dari Tabel 3 dapat dilihat bahwa semua item butir soal memiliki nilai $r_{\text {hitung }}$ yang lebih besar dari $r_{\text {tabel }}$ sehingga semua item butir soal dinyatakan valid.

b. Uji realibilitas instrumen penelitian

Uji realibilitas digunakan untuk mengetahui tingkat ketelitian instrumen. Adapun rumus yang digunakan adalah Alpha karena instrumen berbentuk soal uraian dengan taraf signifikasi $5 \%$ dan $\mathrm{N}=24$ adalah 0,388. Berikut hasil perhitungannya disajikan dalam Tabel 4.

Tabel 4. Hasil Uji Realibilitas Instrumen

\begin{tabular}{ccccc}
\hline Item Butir Soal & $\mathrm{N}$ & $r_{\text {hitung }}$ & $r_{\text {tabel }}$ & Keputusan \\
\hline $\mathrm{X}_{1}, \mathrm{X}_{2}, \mathrm{X}_{3}, \mathrm{X}_{4}$ & 24 & 1,76 & 0,388 & Reliabel \\
\hline
\end{tabular}

c. Data hasil penelitian(Posttest)

Data hasil penelitian diperoleh dari tes hasil belajar atau posttest yang diberikan setelah perlakuan kepada dua kelas. Tes menggunakan instrumen soal uraian materi prisma dan limas sebanyak empat soal. Adapun deskripsi nilai posttest yang diperoleh kelas eksperimen (VIII C) dan kelas kontrol (VIII E) dapat dilihat pada Tabel 5.

Tabel 5. Nilai Rata-rata Posttest

\begin{tabular}{cccc}
\hline Kelas & Nilai Tertinggi & $\begin{array}{c}\text { Nilai } \\
\text { Terendah }\end{array}$ & Rata-Rata \\
\hline Eksperimen & 93 & 30 & 61,71 \\
\hline Kontrol & 87 & 30 & 51 \\
\hline
\end{tabular}

Pada Tabel 5 di atas menunjukkan bahwa adanya perbedaan rata-rata dari kedua kelas. Dari tabel tersebut dapat diketahui bahwa nilai rata-rata kelas eksperimen lebih tinggi daripada nilai rata-rata kelas kontrol dengan selisih 10,71. Artinya kemampuan kompetensi strategis siswa tertinggi perorangan terdapat pada kelas eksperimen sedangkan kemampuan kompetensi strategis terendah perorangan adalah sama pada kedua kelas.

Adapun perbandingan nilai hasil Posttest dari masing-masing item soal pada kelas eksperimen dan kelas kontrol disajikan dalam Tabel 6 berikut.

Tabel 6. Perbandingan Nilai Hasil Posttest

\begin{tabular}{|c|c|c|c|c|c|c|}
\hline \multirow{5}{*}{$\begin{array}{l}\text { Kemampuan } \\
\text { Kompetensi } \\
\text { Strategis } \\
\text { Siswa Kelas } \\
\text { Eksperimen }\end{array}$} & $\begin{array}{l}\text { No } \\
\text { Soal }\end{array}$ & $\mathrm{N}$ & $\begin{array}{l}\text { Skor } \\
\text { Ideal }\end{array}$ & $\begin{array}{c}\text { Jumlah } \\
\text { Benar }\end{array}$ & Rata-rata & $\begin{array}{c}\text { Persentase } \\
(\%)\end{array}$ \\
\hline & 1 & 21 & 12 & 211 & 10,04 & 83,67 \\
\hline & 2 & 21 & 3 & 44 & 2,09 & 69,67 \\
\hline & 3 & 21 & 6 & 94 & 4,47 & 74,5 \\
\hline & 4 & 21 & 9 & 44 & 2,09 & 23,22 \\
\hline \multirow{5}{*}{$\begin{array}{l}\text { Kemampuan } \\
\text { Kompetensi } \\
\text { Strategis } \\
\text { Siswa Kelas } \\
\text { Kontrol }\end{array}$} & $\begin{array}{c}\text { No } \\
\text { Soal }\end{array}$ & $\mathrm{N}$ & $\begin{array}{l}\text { Skor } \\
\text { Ideal }\end{array}$ & $\begin{array}{l}\text { Jumlah } \\
\text { Benar }\end{array}$ & Rata-rata & $\begin{array}{c}\text { Persentase } \\
(\%)\end{array}$ \\
\hline & 1 & 20 & 12 & 226 & 11,30 & 94,17 \\
\hline & 2 & 20 & 3 & 34 & 1,70 & 8,5 \\
\hline & 3 & 20 & 6 & 31 & 1,55 & 7,75 \\
\hline & 4 & 20 & 9 & 10 & 0,50 & 2,5 \\
\hline
\end{tabular}


Dari Tabel 6 dapat dilihat bahwa kemampuan kompetensi strategis siswa pada kelas eksperimen dengan persentase terbesar terdapat pada nomor satu, kemudian diikuti oleh nomor tiga selanjutnya nomor dua dan terakhir dengan persentase terkecil pada nomor empat, ini artinya kemampuan kompetensi strategis siswa kelas eksperimen sudah hampir merata pada tiap indikator kompetensi strategisnya. Sedangkan pada kelas kontrol walaupun pada soal nomor satu persentasenya lebih besar dari persentase kelas eksperimen, akan tetapi untuk soal lainnya lebih sedikit dibandingkan dengan persentase kelas eksperimen. Sehingga dapat dikatakan bahwa rata-rata kemampuan kompetensi startegis siswa kelas eksperimen lebih tinggi daripada kemampuan kompetensi strategis kelas control.

\section{Analisis Data}

Setelah data dari setiap variabel terkumpul, kemudian dianalisis untuk menguji hipotesis penelitian denagn uji-t. Hasil uji-t dapat diketahui setelah dilakukan uji normalitas dan homogenitas data sebagai syarat berlakunya uji-t. Analisis dilakukan terhadap data yang didapatkan setelah perlakuan terhadap kelas eksperimen dan kelas kontrol, kedua kelas tersebut diberikan posttest yang digunakan untuk mengetahui perbedaan kemampuan kompetensi strategis siswa. Diperoleh data sebagai berikut:

Uji normalitas yang digunakan adalah chi kuadrat $\left(\chi^{2}\right)$. Uji normalitas digunakan untuk mengetahui apakah data berasal dari populasi yang berdistribusi normal atau tidak, denngan kriteria $\chi^{2}{ }_{\text {hitung }} \leq \chi^{2}$ tabel diukur pada taraf signifikasi dan tingkat kepercayaan tertentu. Berikut disajikan hasil uji normalitas dari hasil posttestkemampuan kompetensi strategis siswa yang berasal dari kelas eksperimen dan kelas kontrol pada Tabel 7.

Tabel 7. Uji Normalitas Kemampuan Kompetensi Strategis Siswa

Kelas Eksperimen dan Kelas Kontrol

\begin{tabular}{cccccc}
\hline Kelas & $\mathbf{N}$ & $\begin{array}{c}\text { Taraf } \\
\text { sigifikasi }\end{array}$ & $\chi^{2}{ }_{\text {hitung }}$ & $\chi^{2}{ }_{\text {tabel }}$ & Keterangan \\
\hline Eksperimen & 21 & 0,05 & 10,98 & 11,07 & Berdistribusi nomal \\
\hline Kontrol & 20 & 0,05 & 7,34 & 11,07 & Berdistribusi nomal
\end{tabular}

Karena $\chi_{\text {hitung }}^{2}$ pada kedua kelas kurang dari $\chi_{\text {tabel }}^{2}$ maka dapat disimpulkan bahwa data populasi kedua kelompok berdistribusi normal.

Uji homogenitas varians digunakan untuk mengetahui apakah kedua kelas sampel berasal dari populasi yang sama (homogen) atau berbeda (heterogen). Dalam penelitian ini, uji homogenitas yang digunakan adalah uji F. kriteria pengujian yang digunakan yaitu kedua kelas dikatakan homogen apabila $F_{\text {hitung }} \leq \mathrm{F}_{\text {tabel }}$ diukur pada taraf signifikasi dan tingkat kepercayaan tertentu. Untuk lebih jelasnya, hasil perhitungan uji homogenitas dari hasil posttest siswa yang berasal dari kelas eksperimen dan kelas control dapat dilihat pada Tabel 8. 
Tabel 8. Hasil Uji Homogenitas

\begin{tabular}{|c|c|c|c|c|c|}
\hline \multirow[b]{2}{*}{ Kelas } & \multirow[b]{2}{*}{$\begin{array}{l}\text { Jumlah } \\
\text { Sampel }\end{array}$} & \multirow[b]{2}{*}{$\begin{array}{c}\text { Varians } \\
\left(\mathbf{s}^{2}\right)\end{array}$} & \multicolumn{2}{|c|}{$\mathbf{F}$} & \multirow[b]{2}{*}{ Kesimpulan } \\
\hline & & & Hitung & $\begin{array}{c}\text { Tabel } \\
\alpha=0,05\end{array}$ & \\
\hline Eksperimen & 21 & 236,71 & \multirow{2}{*}{1,48} & \multirow{2}{*}{2,63} & \multirow{2}{*}{ Homogen } \\
\hline Kontrol & 20 & 159,21 & & & \\
\hline
\end{tabular}

Karena Fhitung kurang dari $\mathrm{F}_{\text {tabel }}(1,48 \leq 2,63)$ maka $\mathrm{H}_{0}$ diterima, artinya kedua varians homogen. Hasil perhitungan uji-F memperlihatkan bahwa data kemampuan kompetensi strategis siswa kelas eksperimen dan kelas kontrol mempunyai varians yang sama(homogen).Karena jumlah anggota sampel $n_{1} \neq n_{2}$ dan varians homogen maka rumus yang digunakan untuk pengujian hipotesis uji-t adalah rumus Polled varians dengan taraf signifikasi $5 \%$ dan derajat kebebasan $(\mathrm{db})=\mathrm{n}$ - jumlah sampel, $(\mathrm{db})$ $=39$, diperoleh harga $t_{\text {tabel }(\alpha=0,05)}=1,69$. Adapun hasil analisis dari hasil posttest kemampuan kompetensi strategis siswa kelas eksperimen dan kelas kontrol dapat dilihat pada Tabel 9.

Tabel 9. Hasil Uji Hipotesis

\begin{tabular}{|c|c|c|c|}
\hline Kelas & $t_{\text {hitung }}$ & $t_{\text {tabel }(\alpha=0,05)}$ & kesimpulan \\
\hline $\begin{array}{c}\text { Eksperimen } \\
\text { Kontrol }\end{array}$ & 2,43 & 1,69 & $\mathrm{H}_{0}$ ditolak \\
\hline
\end{tabular}

Dari Tabel terlihat bahwa $t_{\text {hitung }}>t_{\text {tabel }}(2,43>1,69)$ maka dapat disimpulkan bahwa $\mathrm{H}_{0}$ ditolak dan $\mathrm{H}_{\mathrm{a}}$ diterima dengan signifikasi $5 \%$ sehingga dapat dikatakan bahwa model pembelajaran Conceptual Understanding Procedures efektif terhadap kemampuan kompetensi strategis siswa.

\section{Pembahasan}

Dari hasil pengujian hipotesis terdapat perbedaan rata-rata kemampuan kompetensi strategis siswa antara kelas eksperimen dan kelas kontrol. Hal tersebut menunjukkan bahwa pembelajaran matematika dengan model pembelajaran Conceptual Understanding Procedures lebih efektif daripada pembelajaran siswa dengan metode pembelajaran langsung. Ini dikarenakan metode CUPs memuat beberapa langkah dalam pelaksanaannya yang mengharuskan siswa untuk menyampaikan dan mengembangkan ide matematikanya yang walaupun dalam pelaksanaan pembelajarannya juga hampir sama. Temuan penelitian ini didukung oleh penelitian sebelumnya yang dilakukan oleh Fera Ismawati (2013) tentang "Penerapan model pembelajaran CUPs untuk meningkatkan pemahaman konsep dan curiosity siswa" yang mengungkapkan bahwa siswa yang pembelajarannya menggunakan pendekatan konstruktivisme menunjukkan peningkatan pemahaman konsep dan curiosity siswa dengan skor rata-rata yang lebih besar daripada siswa dengan pembelajaran langsung.

Hasil pengamatan sebelum dilakukan pembelajaran dengan model CUPs, kegiatan berpusat pada guru. Pembelajaran yang cendrung abstrak, diberikan secara klasikal dan satu arah dari guru kepada murid melalui metode ceramah tanpa banyak melihat kemungkinan penerapan metode pembelajaran lain yang sesuai membuat proses belajar 
matematika siswa yang kurang bermakna. Selain itu, karena pembelajaran yang bersifat monoton beberapa siswa terlihat tidak tertarik untuk mengikuti proses kegiatan belajar sehingga banyak yang mengobrol dengan teman-temannya.

Kelas eksperimen yang pembelajarannya menggunakan metode CUPs pada setiap pertemuannya melalui tahapan-tahapan pembelajaran yang mana dalam tahapan pertama, siswa memperhatikan demonstrasi contoh soal dan mengerjakan LKS guna mengetahui pemahaman individu siswa, tahapan kedua siswa melakukan kegiatan eksperimen kerja kelompok masing-masing, dan tahapan ketiga siswa melakukan presentasi kelas berdasarkan kelompok yang sudah disepakati. Model pembelajaran CUPs merupakan salah satu metode dalam pembelajaran matematika yang menuntut siswa untuk meningkatkan kemampuan matematis dalam belajar matematika yang salah satunya adalah kompetensi strategis siswa. Terbukti kemampuan kompetensi strategis siswa dari hasil belajar kelas eksperimen lebih tinggi dibanding kelas kontrol.

Setelah siswa sudah mulai terbiasa dengan pembelajaran CUPs, siswa jadi sedikit antusias untuk maju kedepan kelas ketika diberikan tugas, walaupun jumlahnya masih sedikit. Pada kelas kontrol juga masih sedikit siswa yang mempunyai kemampuan kompetensi strategis karena proses pembelajarannya melalui penjelasan guru, proses pembelajarannya juga hampir sama karena pembelajaran langsung juga merupakan cooperative learning. Berbeda dengan kelas eksperimen yang pembelajarannya lebih berpusat pada siswa dan bersifat mandiri, pada kelas kontrol siswa tidak secara langsung menemukan konsep tapi melalui penjelasan guru. Guru sebagai pusat pembelajaran, tetapi jika siswa hanya melihat tanpa ikut dalam proses akan sulit untuk menemukan konsep-konsep matematika lainnya. Maka diperlukan interaksi agar siswa tidak hanya melihat tetapi ikut memberikan gagasan dalam merumuskan konsep walaupun tidak secara langsung. Pada proses interaksi guru dan siswa ini, diharapkan dapat membantu siswa dalam mengembangkan pemehaman konsep, kompetensi strategis serta kemampuan matematis lainnya.

Berdasarkan hasil analisis data diperoleh rata-rata skor kemampuan kompetensi strategis siswa kelas eksperimen sebesar 61,71. Hasil ini lebih tinggi jika dibandingkan dengan nilai rata-rata skor kemampuan kompetensi strategis siswa kelas kontrol yaitu sebesar 51. Hal ini sejalan dengan hasil uji hipotesis dimana $\mathrm{H}_{\mathrm{a}}$ diterima, yang mana rata-rata kemampuan kompetensi strategis siswa kelas eksperimen lebih tinggi dibandingkan kemampuan kompetensi strategis kelas kontroldengan hipotesis $\mathrm{H}_{\mathrm{a}}$ adalah model pembelajaran Conceptual Understanding Procedures (CUPs) efektif terhadap kompetensi strategis siswa kelas VIII SMPN 2 Labuapi.

\section{SIMPULAN DAN SARAN}

Berdasarkan hasil penelitian yang sudah dibahasakan sebelumnya dapat disimpulkan bahwa: (1) Model pembelajaran Conceptual Understanding Procedures (CUPs) cukup efektif terhadap kompetensi strategis siswa SMP Negeri 2 Labuapi kelas VIII.Hal ini dapat dilihat dari nilai rata-rata kemampuan kompetensi strategis siswa yang menggunakan model pembelajaran CUPslebih tinggi dari pada rata-rata kemampuan kompetensi strategis siswa yang menggunakan model pembelajaran 
langsung; (2) Model pembelajaran CUPs melalui 3 tahapan pembelajaran yang mana dalam tahapan pertama, siswa memperhatikan demonstrasi contoh soal dan mengerjakan LKS guna mengetahui pemahaman individu siswa, tahapan kedua siswa melakukan kegiatan eksperimen kerja kelompok, dan ketiga siswa melakukan presentasi kelas berdasarkan kelompok yang sudah disepakati.Proses pembelajaran CUPs harus ditingkatkan lagi dalam setiap tahapannya, terutama dalam tahapan individu guna meningkatkan nilai, kreatifitas, dan kompetensi strategis yang merupakan kemampuan matematis yang harus dimiliki siswa.

Berdasarkan temuan yang penulis temukan dalam penelitian ini, ada beberapa saran penulis terkai penelitian ini, diantaranya (1) Berdasarkan hasil penelitian bahwa pembelajaran matematika dengan model pembelajaran Conceptual Understanding Procedures (CUPs) mampu meningkatkan kompetensi strategis siswa, sehingga pembelajaran tersebut dapat menjadi salah satu variasi pembelajaran matematika yang diterapkan oleh guru; (2) Penelitian berikutnya mungkin dapat dikembangkan lagi, baik dari penggunaan indikator-indikator kompetensi strategis yang belum diteliti; (3) Dengan adanya beberapa keterbatasan dalam pelaksanaan penelitian ini, sebaiknya dilakukan penelitian lanjut yang meneliti tentang pembelajaran Conceptual Understanding Procedures (CUPs) pada pokok bahasan lain dengan mengukur aspek lain ataupun jenjang sekolah yang berbeda.Guru yang hendak menggunakan model pembelajaran Conceptual Understanding Procedures (CUPs) dalam pembelajaran matematika diharapkan dapat mendisain, mengembangkan, memperhatikan beberapa variabel yang mendukung sehingga pemebelajaran di kelas bisa seefektif mungkin dan selesai tepat waktu.

\section{REFERENSI}

Ade Rahayu Fadhilla, Marwan AR, and Susilawati. 2016. "Penerapan Model Pembelajaran Conceptual Undrstanding Procedures (Prosedur Pemahaman Konsep) Untuk Meningkatkan Hasil Belajar Pada Materi Cahaya Kelas VIII Di SMPN 2 Montasik Aceh Besar." Jurnal Ilmiah Mahasiswa (JIM) Pendidikan Fisika 1(4): 104-9.

Aribawati, D, F Kristin, and ... 2018. "Penerapan Model Pembelajaran Inkuiri Terbimbing Untuk Meningkatkan Kreativitas Dan Hasil Belajar IPA SISWA KELAS 3 SD." JUSTEK/ Jurnal Sains \& ....

Arikunto, Suharsimi. 2006. "Prosedur Penelitian Tindakan Kelas." Bumi Aksara 136(2): 2-3.

Arta Diantoro, Syaiful Barsa, Mahsup Mahsup, and Dewi Pramita. 2019. "Penerapan Model Pembelajaran Kooperatif Tipe Two Stay Two Stray (TSTS) Dalam Meningkatkan Hasil Belajar Bentuk Aljabar Siswa Kelas VII SMP." Paedagoria / FKIP UMMat 10(1): 01.

Dantes, N. 2007. "Pendidikan Profesi Guru Dalam Kaitannya Dengan Peningkatan Profesionalisme Guru (Refleksi Tentang Struktur Program LPTK).” Jurnal Pendidikan dan Pengajaran UNDIKSHA,(Online ....

Dwiranata, Doni, Dewi Pramita, and Syaharuddin Syaharuddin. 2019. "Pengembangan Media Pembelajaran Matematika Interaktif Berbasis Android Pada Materi Dimensi Tiga Kelas X SMA." Jurnal Varian 3(1): 1-5.

Gita, Asri, Nerru Pranuta Murnaka, and Klara Iswara Sukmawati. 2018. "Penerapan Model Pembelajaran Conceptual Understanding Procedures (CUPS) Sebagai Upaya 
Mengatasi Miskonsepsi Matematis Siswa." Journal of Medives: Journal of Mathematics Education IKIP Veteran Semarang 2(1): 65.

Herianto, Agus, and Ibrahim Ibrahim. 2017. "Analisis Efektivitas, Kelebihan Dan Kekurangan Desain Model Cooperative Learning Dalam Meningkatkan Motivasi Dan Hasil Belajar Geografi Lingkungan Pada Mahasiswa Program Studi Pendidikan Geografi Di Pulau Lombok." In Prosiding Seminar Nasional Pendidik Dan Pengembang Pendidikan Indonesia Dengan Tema "Membangun Generasi Berkarakter Melalui Pembelajaran Inovatif". Aula Handayani IKIP Mataram 14 Oktober 2017, , 17-27.

Hikmah, Nurul, Baidowi Baidowi, and Nani Kurniati. 2014. "Penerapan Model Pembelajaran Conceptual Understanding Procedures (CUPs) Untuk Meningkatkan Aktivitas Dan Hasil Belajar Matematika Siswa Kelas X SMA NEGERI 7 Mataram." JURNAL PIJAR MIPA 9(2).

Kabunggul, Yosua et al. 2020. "Meningkatkan Motivasi Dan Hasil Belajar Siswa Melalui Penerapan Model Pembelajaran Team Game Tournament Berbantuan Media ...." Jurnal Pendidikan Karakter 3(2): 3-6.

Mahsup, and Y. S. Anwar. 2020. "Development of Structured Modules to Improve the Mathematical Understanding of the Circle Concept in Class VIII Mataram 17 Junior High School." In Journal of Physics: Conference Series,

Mahsup, Abdillah, Syaharuddin. 2018. "Peningkatan Penguasaan Konsep Lingkaran Dengan Metode Penemuan Bagi Mahasiswa." Paedagoria 9(2): 91-96. http://journal.ummat.ac.id/index.php/paedagoria/article/view/871.

Muhardini, Sintayana et al. 2020. "Pengembangan Media Pembelajaran Box Nusantara Untuk Membentuk Kemampuan Memahami Konsep Tematik Pada Siswa Sekolah Dasar." Jurnal Kependidikan: Jurnal Hasil Penelitian dan Kajian Kepustakaan di Bidang Pendidikan, Pengajaran dan Pembelajaran 6(2): 284.

Permendikbud RI No. 20. 2016. "Standar Kompetensi Lulusan Pendidikan Dasar Dan Menengah." In Lampiran Peraturan Menteri Pendidikan Dan Kebudayaan Republik Indonesia Nomor 20 Tahun 2016,.

Puspita, M, S Slameto, and ... 2018. "Peningkatkan Hasil Belajar Matematika Siswa Kelas 4 Sd Melalui Model Pembelajaran Problem Based Learning." Justek/ Jurnal Sains \& ....

Rahmatin, Nutia, Dewi Pramita, Sirajuddin Sirajuddin, and Mahsup Mahsup. 2019. "Pengembangan Modul Pembelajaran Bangun Ruang Dengan Metode Creative Problem Solving (CPS) Pada Siswa Kelas VIII SMP." JTAM / Jurnal Teori dan Aplikasi Matematika 3(1): 27.

Setyowati, Endah, Firosalia Kristin, and Indri Anugraheni. 2018. "Penggunaan Model Pembelajaran Discovery Learning Untuk Meningkatkan Kreativitas Dan Hasil Belajar Siswa Kelas 5 SD Negeri Mangunsari 07." JUSTEK/ Jurnal Sains \& Teknologi 1(1): 76-81.

Sistem Pendidikan Nasional. 2003. “Undang-Undang No.20 Tahun 2003Sistem Pendidikan Nasional. (2003). Undang-Undang No.20 Tahun 2003. Departemen Pendidikan Nasional." Departemen Pendidikan Nasional.

Sugiyono. 2013. "Buku - Sugiyono." In Metode Penelitian Kuantitatif, Kualitatif, Dan R \& $D, 407$.

Syaharuddin, Syaharuddin, Dewi Pramita, and Sirajuddin Sirajuddin. 2019. "Pengenalan Operasi Tambah Kurang Melalui Permainan Congklak Bagi Siswa Sekolah Dasar.” JMM (Jurnal Masyarakat Mandiri) 3(1): 01.

UURI, 20 tahun 2003. 2003. "Undang-Undang Nomor 20 Tahun 2003 Tentang Sistem Pendidikan Indonesia." Indonesia. 